\title{
Acute Toxicity Study of Durian Mesocarpium Ethanol Extracts (Durio Zibethinus Linn) in Healthy Mice
}

\author{
Fitrianingsih ${ }^{1, *}$ Fathnur Sani K ${ }^{1}$, Diah Tri Utami ${ }^{1}$ \\ ${ }^{1}$ Department of Pharmacy, Faculty of Medicine and Health Science, Universitas Jambi, Jambi, Indonesia. \\ *Corresponding author.Email: fitrianingsih@unja.ac.id
}

\begin{abstract}
Durian (Durio zibethinus Linn.) has been shown to have toxicity effect on acute toxicity in vivo. Objective: This study aimed to determine the acute toxicity of the Durian Mesocarpium Ethanol Extracts (EEMD), various doses of Durian Mesocarpium Ethanol Extracts (EEMD) by examining in vivo to the healthy mice experimentally. The toxic effects appeared in a short time after 24 hours by oral administrations of the dosages. This study used completely randomized design. The animals used in this study were mice (Swiss Webster), with criteria are healthy, male, and the range of the ages were $2-3$ months with the body weight $20-30 \mathrm{~g}$. The various dosages of Durian Mesocarpium Ethanol Extracts (EEMD) were divided into six experimental groups to determine the $\mathrm{LD}_{50}$ there are $\mathrm{K}-(\mathrm{NaCMC}) ; \mathrm{P} 1(100 \mathrm{mg} / \mathrm{KgBW})$; P2 (200 mg/KgBW); P3 (400 mg/KgBW); P4 (800 mg/KgBW); P5 (1600 mg/KgBW). The result showed that Durian Mesocarpium Ethanol Extracts (EEMD) has $\mathrm{LD}_{50} 400 \mathrm{mg} / \mathrm{KgBW}$ which included in moderate toxicity with effect like tremor which is one of type acute toxicity due to healthy mice. Conclusion: Based on these results, Durian (Durio zibethinus Linn.) have moderate toxicity after 24 hours oral administration dosages.
\end{abstract}

Keywords: Acute Toxicity, Durian Mesocarpium, Ethanol Extracts, $L D_{50}$.

\section{INTRODUCTION}

Nowadays, medicine therapy paradigms or strategy in the treatment of the diseases has changed by the time. The synthetic drugs usually used in treating the diseases have higher effectivity in the treatment. However, there are so many health problems caused by long term use of its. Based on [1] there is an increase in herbal formulations consumption because of their effectivity in treating the diseases meanwhile they are organic and harmless [2] they are also less damaging and safer than synthetic drugs with less side effects to the biological system in our body [3] Indonesia, as one of the developing countries in South East Asia Nations, its known as a tropical country with many medicinal plants.

One of the medicinal plants in Indonesia and become commodity plants is Durian. It has been used alternatively as traditional medicines. The previous study reported that Durian has some activities like antibacterial [4] anti-inflammation [5][6] antioxidant [5][6] anti hyperuricemia [7], etc. Durian contains many metabolic seconder compounds such as esters ethyl propanoate, methyl-2-methylbutanoate, propyl propanoate, sulphur compounds (diethyl disulphide, diethyl trisulphide and ethanethiol), thioacetals (1-(methylthio)-propane), thioesters (1-(methylthio)-ethane), thiolanes (3,5dimethyl-1,2,4-trithiolane isomers), alcohol (ethanol) [8][9][0] and polyphenols (flavonoids, phenolic acid, tannins, and other bioactive components). Based on epidemiological studies, the polyphenols compound has effectivity in the treatment of chronic diseases such as cancers, cardiovascular diseases and diabetes $[10][11][12][13][14][15]$. Toxicity study from the Malvaceae family has reported having moderate toxicity to female rats with $\mathrm{LD}_{50}$ values of $850.90 \mathrm{mg} / \mathrm{kg} \mathrm{BW}$ [16]. However, there are limited studies have been reported about toxicity of its bioactive compounds. This study aims to assess the acute toxicity effect of Durian mesocarpium in healthy mice to get more scientific information about the evaluation of its toxicological implications.

\section{METHODS}

\subsection{Material}

Durian rinds (Durio zibethinus L.) consists of ethanol distillate $70 \%$, Na CMC, aquadest. Durian rinds samples were obtained from Simpang Selat Village, Jaluko District, Muaro Jambi Regency, Jambi Province. 
For the ethanol extract preparation, formula Durian rinds $40 \mathrm{~kg}$ (Durio zibethinus L.) macerated in ethanol $70 \%$. Extraction was initiated with ethanol solvent in 24 hours. This process is repeated in three times until colorless. Then, it was thickened with a rotary evaporator to obtain the viscous extract.

\subsection{Animal}

The animals used were 36 healthy male white mice with a body weight of 20-30 grams and aged 5-6 weeks. Before being given the treatment, the animals were acclimatized for 7 days.

\subsection{Acute Toxicity Study}

This study uses post-test only controlled group design using 36 animals. The animals were divided into six treatment groups with consist of six mice:

1. K- (Negative Control): Na CMC 0.5\%

2. P1 group

: EEMD $100 \mathrm{mg} / \mathrm{KgBW}$

3. P2 group

: EEMD $200 \mathrm{mg} / \mathrm{KgBW}$

4. P3 group

: EEMD 400mg/KgBW

5. $\mathrm{P} 4$ group

: EEMD $800 \mathrm{mg} / \mathrm{KgBW}$

6. P5 group

: EEMD $1600 \mathrm{mg} / \mathrm{KgBW}$

The animals were fasted from food but they still drank water. Then, the animal was weighed and given a test preparation. After getting the treatment, the food was given back after 1-2 hours. The symptoms of toxicity that appeared in mice were observed periodically for the first 4 hours and once a day for 7 days. Toxicity symptoms were observed, such as mice becoming silent, tremor, grooming, weakness, diarrhea, twitching in the body of the mice, changes in skin and eye color, diarrhea and death. The $\mathrm{LD}_{50}$ value is determined by counting the number of animal deaths for 24 hours due to the provision of the test preparation at each doses level [17].

The Thompson Weil Method used to determine the $\mathrm{LD}_{50}$.

$$
\log m=\log D+d(f+1) \ldots \ldots
$$

\subsection{Data Analysis}

The data were analysed and represented in the tables descriptively.

\section{RESULTS}

\subsection{The Non Specific Parametric}

Based on the result obtained, the crude extract of mesocarpium Durian rinds have a water content of $8.87 \%$ and ash content of $15 \%$ (Table 1). It was found that the crude extracts used in this study contained metabolic seconder compounds, such as alkaloids, flavonoids, saponins, tannins and phenolics.

Table 1. Non Specific Parametric

\begin{tabular}{|l|c|}
\hline Parameter & Analysis Result (\%) \\
\hline Water Percentage & 8.87 \\
\hline Ash Percentage & 15.00 \\
\hline
\end{tabular}

\subsection{Acute Toxicity Treatment}

Table 2. Percentage of Accumulation in Treatment Groups (\%)

\begin{tabular}{|l|c|c|c|c|c|c|}
\hline \multirow{2}{*}{ Parameters } & \multicolumn{5}{|c|}{ Percentage of Accumulation in Treatment Groups (\%) } \\
\cline { 2 - 7 } & K & P1 & P2 & P3 & P4 & P5 \\
\hline Silent & 0 & 43.33 & 16.67 & 56.67 & 53.33 & 30 \\
\hline Tremor & 0 & 0 & 0 & 0 & 3.33 & 6.67 \\
\hline Grooming & 0 & 10 & 6.67 & 20 & 30 & 50 \\
\hline Lethargy & 0 & 0 & 3.3 & 6.7 & 3.3 & 23.3 \\
\hline Sleep & 0 & 0 & 0 & 0 & 0 & 6.67 \\
\hline Diarrhea & 0 & 0 & 0 & 0 & 0 & 0 \\
\hline Somatomotor activity & 0 & 0 & 10 & 3.33 & 6.67 & 0 \\
\hline $\begin{array}{l}\text { Changes in skin and } \\
\text { fur }\end{array}$ & 0 & 0 & 0 & 0 & 0 & 0 \\
\hline Salivation & 0 & 0 & 0 & 0 & 0 & 0 \\
\hline
\end{tabular}


Mostly, the percentage of accumulated symptoms has increased in each treatment group and the highest percentage of accumulation is shown in the P5 treatment group, where this is due to the high dose of ethanol extract of mesocarpium Durian to experimental animals. The value of $\mathrm{LD}_{50}$ was obtained from the number of dead and living mice in each group. Furthermore, the $\mathrm{LD}_{50}$ The
(Table 2). Therefore, the highest percentage that shown one of toxicity effect which is silent effect was P3 with $56.67 \%$, but for grooming was P5 with $50 \%$.

\subsection{Determination of $L D_{50}$}

$\mathrm{LD}_{50}$ value is caWlculated using the Thompson-Weil method (Table 3).

Table 3. Number of Death

\begin{tabular}{|c|c|c|c|}
\hline Groups & Number of Mices & $\begin{array}{c}\text { Doses } \\
\text { (mg/20 g BW mices) }\end{array}$ & $\begin{array}{c}\text { Number of } \\
\text { Death }\end{array}$ \\
\hline K & 6 & 0 & 0 \\
\hline P1 & 6 & 100 & 0 \\
\hline P2 & 6 & 200 & 0 \\
\hline P3 & 6 & 400 & 1 \\
\hline P4 & 6 & 800 & 1 \\
\hline P5 & 6 & 1600 & 2 \\
\hline
\end{tabular}

The $\mathrm{LD}_{50}$ value obtained from the Thompson-Weil calculation is $400 \mathrm{mg} / \mathrm{kgBW}$ and included in the moderate toxic category.

\section{DISCUSSION}

Based on our study, the toxicity symptoms that appeared during the observation probably caused by the flavonoid compounds present in the Durian rinds. The acute toxicity effect in each treatment group reported in this study showed that the number of deaths increases as the dose increases. Thus, influenced by the role of the flavonoid compounds contained in this EEMD sample. The flavonoid compound has activities that cause depression in the central nervous system [18][19]. The occurrence of depression can cause cell death due to the cessation of active transport mechanisms in delivering and entering ions in the body. Flavonoid compounds have reported in depressing the central nervous system [19]. Flavonoids contain phenolic compounds. Excessive flavonoids in the cell environment cause the $-\mathrm{OH}$ group on the flavonoids to bind to the cell membrane integral protein [20]. It causes active transport to be blocked. The interrupted active transport causes uncontrolled entry of ions into the cell, which leads to cell death. The result that we obtained showed variation value, which means that EEMD samples were still in crude extracts, that might be potentially inhibition by other compounds in it.

\section{CONCLUSION}

The result showed that Durian Mesocarpium Ethanol Extracts (EEMD) has LD $50400 \mathrm{mg} / \mathrm{KgBW}$ which included in moderate toxicity category with effect like tremor which is one of type acute toxicity due to healthy mice. Based on these results, Durian (Durio zibethinus Linn.) has moderate toxicity after 24 hours oral administration dosages.

\section{ACKNOWLEDGMENTS}

This research was funded by LPPM grants (Research and Community Services Institution) Universitas Jambi in Scheme of Innovation Research.

\section{REFERENCES}

[1] J. N. M. Shri. 2003. Ginger: It's role in xenobiotic metabolism, ICMRBull, 33(6), pp. 57-63. http://dx.doi.org/10.1016/j.jep.2013.12.034

[2] A. Arya, A. A. Mahmood, S. H. Batoul, \& A. M. Mustafa. 2012. Screening for hypoglycemic activity on the leaf extracts of nine medicinal plants: In-vivo evaluation, E-Journal of Chemistry, 9(3). pp. 11961205. https://doi.org/10.1155/2012/103760

[3] D. S. Fabricant, \& N. R. Fansworth. 2001. The value of plants used in traditional medicine for drug discovery, Environmental Health Perspectives, 109(1), pp. 69-76. https://doi.org/10.1016/00766879(90)86135-I

[4] F. Fitrianingsih, A. Soyata, S. Wigati. 2019. The Antibacterial Activities of Durian Rinds Extract (Durio zibethinus) Against Propionibacterium acne, IOP Conf. Series: Earth and Environmental Science 391. https://10.1088/17551315/391/1/012013 
[5] H. Leontowicz, M. Leontowicz, R. Haruenkit, S. Poovarodom, Z. Jastrzebski, J. Drzewiecki, A. L. M. Ayala, I. Jesion, S. Trakhtenberg, S. Gorinstein. 2008. Durian (Durio zibethinus Murr.) cultivars as nutritional supplementation to rat's diets, Food and Chemical Toxicology, 46. pp. 581-589. https://doi:10.1016/j.fct.2007.08.042

[6] P. Chingsuwanrote, C. Muangnoi, K. Parengam, and S. Tuntipopipat. 2016. Antioxidant and antiinflammatory activities of durian and rambutan pulp extract, International Food Research Journal, 23 (3), $\quad$ pp. $\quad 939 \quad$ - 947. http://ifrj.upm.edu.my/23\%20(03)\%202016/(5).pdf

[7] R. Sonia, Yusnelti, Fitrianingsih. 2020. The Effectivity of Ethanol Extracts of Durio zibethinus (Linn.) Leaves as Antihyperuricemia, Jurnal Kefarmasian Indonesia, 10 (2), pp. 130 - 139. https://10.22435/jki.v10i2.2148

[8] M. Belgis, C. H, Wijaya, A. Apriyantono, B. Kusbiantoro, N. D. Yuliana. 2016. Physicochemical differences and sensory profiling of six lai (Durio kutejensis) and four durian (Durio zibethinus) cultivars indigenous Indonesia, Int. Food Res. J. 23, pp.

1466-1473.

https://www.researchgate.net/publication/3054095

83_Physicochemical_differences_and_sensory_pro filing_of_six_lai_Durio_kutejensis_and_four_duria $\underline{\mathrm{n} \text { DDurio_zibethinus_cultivars indigenous Indones }}$ ia

[9] S. -T. Chin, S. A. H. Nazimah, S. Y. Quek, Y. B. C. Man, R. A. Rahman, D. M. Hashim. 2007. Analysis of volatile compounds from Malaysian durians (Durio zibethinus) using headspace SPME coupled to fast GC-MS, J. Food Compost. Anal, 20, pp. 3144. https://doi.org/10.1016/j.jfca.2006.04.011

[10] N. A. A. Aziz, A. M. M. Jalil. 2019. Bioactive Compounds, Nutritional Value, and Potential Health Benefits of Indigenous Durian (Durio Zibethinus Murr.): A Review, Foods, 2019, 8, 96, pp. 1 - 18. https://doi.org/10.3390/foods8030096

[11] C. Costa, A. Tsatsakis, C. Mamoulakis, M. Teodoro, G. Briguglio, E. Caruso, D. Tsoukalas, D. Margina, D. Efthimious, D. Kouretas, et al. 2017 Current evidence on the effect of dietary polyphenols intake on chronic diseases. Food Chem. Toxicol.110, pp. 286-299. https://doi.org/10.1016/j.fct.2017.10.023

[12] W. R. Leifert, M. Y. Abeywardena. 2008. Grape seed and red wine polyphenol extracts inhibit cellular cholesterol uptake, cell proliferation, and 5lipoxygenase activity, Nutr. Res, 28, pp. 842-850. https://doi.org/10.1016/j.nutres.2008.09.001

[13] E. Mostofsky, M. B. Johansen, M. A. Tjønneland, H. S. Chahal, M. A. Mittleman, K. Overvad. 2017. Chocolate intake and risk of clinically apparent atrial fibrillation: The Danish Diet, Cancer, and Health Study. Heart. 103, pp. 1163-1167. https://dx.doi.org/10.1136\%2Fheartjnl-2016$\underline{310357}$

[14] S. L. Schmit, H. S. Rennert, S. B. Gruber. 2016. Coffee consumption and the risk of colorectal cancer. Cancer Epidemiol. Biomark. Prev. 25, pp. 634-639. https://doi.org/10.1158/1055-9965.epi15-0924

[15] S. Oba, C. Nagata, K. Nakamura, K. Fujii, T. Kawachi, N. Takatsuka, H. Shimiz. 2010. Consumption of coffee, green tea, oolong tea, black tea, chocolate snacks and the caffeine content in relation to risk of diabetes in Japanese men and women. Br. J. Nutr, 103, pp. 453-459. https://10.1017/S0007114509991966

[16] F. Sari, Nurkhasanah, M. S. Bachri. 2016. Acute Toxicity Test Of Rosella (Hibiscus sabdariffa L.) Calyx Ethanolic Extract On Sprague Dawley, 21(1), 2016, pp. 12-18. https://doi.org/10.22146/tradmedj.10673

[17] OECD 407. Guidelines for the testing of chemicals. Acute oral toxicity -Fixed dose procedure. OECD/OCDE 407. Paris: OECD Publishing. 2020, August 1. https://doi.org/10.1787/9789264071001$\underline{\text { en }}$

[18] S. P. Fernandez, C. Wasowski, L. M. Loscalzo, R. E. Granger, G. A. R. Johnston, A. C. Paladini, and M. Marder. 2006. Central Nervous System Depressant Action Of Flavonoid Glycosides, European Journal of Pharmacology, 539(1), 2006, pp. 168-176. https://doi.org/10.1016/j.ejphar.2006.04.004

[19] H. K. Sandhar, B. Kumar, S. Prasher, P. Tiwari, M. Salhan, P. Sharma. 2011. Review of Phytochemistry and pharmacology of flavonoids, Internationale Pharmaceutica Sciencia, 1(1), 2011, pp. 25-41.

[20] V. J. Desmet, M. Gerber, J. H. Hoofnagle, M. Manns, P. J. Schuer. 1994. Classification of Cronic Hepatitis: Diagnosis, Grading and Staging, Hepatology, 19 (6). pp. 1513-1520. https://doi.org/10.1002/hep.1840190629 